\title{
Genetic variability of Brazilian rice landraces determined by SSR markers
}

\author{
Tereza Cristina de Oliveira Borba(1), Clistiane dos Anjos Mendes ${ }^{(1)}$, Élcio Perpétuo Guimarães ${ }^{(1)}$, \\ Tuliana Oliveira Brunes ${ }^{(1)}$, Jaime Roberto Fonseca ${ }^{(1)}$, Rosana Vianello Brondani ${ }^{(1)}$ and Claudio Brondani ${ }^{(1)}$
}

\begin{abstract}
(1)Embrapa Arroz e Feijão, Rodovia Goiânia-Nova Veneza, Km 12, CEP 75375-000 Santo Antônio de Goiás, GO, Brazil. E-mail: tereza@cnpaf.embrapa.br, clisagroma@hotmail.com, elcio.guimaraes@fao.org, brunestuliana@gmail.com, jfonseca@cnpaf.embrapa.br, rosanavb@cnpaf.embrapa.br, brondani@cnpaf.embrapa.br
\end{abstract}

\begin{abstract}
The objective of this study was to evaluate the genetic variability of rice (Oryza sativa) landraces collected in Brazilian small farms. Twelve simple sequence repeat (SSR) markers characterized 417 landraces collected in 1986, 1987 and 2003, in the state of Goiás, Brazil. The number of landraces with long and thin grain type increased in the evaluated period, probably due to market demand. Based on the molecular data, the genetic variability increased during this period and, as per to the factorial correspondence analysis, most of the accessions were grouped according to the year of collection. The incorporation of modern rice cultivars in landrace cultivation areas and the selection carried out by small farmers are the most probable factors responsible for increasing landrace genetic variability, during the evaluated period. Genotype exchange between farmers, selection practice and local environmental adaptation are able to generate novel adapted allele combinations, which can be used by breeding programs, to reinitiate the process.
\end{abstract}

Index terms: Oryza sativa, genotyping, microsatellites, participatory breeding, rice breeding.

\section{Variabilidade genética de variedades locais de arroz determinada por marcadores SSR}

Resumo - O objetivo deste trabalho foi avaliar a variabilidade genética de variedades locais de arroz (Oryza sativa), coletadas em pequenas propriedades rurais. Doze marcadores microssatélites (SSR) caracterizaram 417 variedades locais, coletadas em 1986, 1987 e 2003, no Estado de Goiás. O número de variedades locais com tipo de grão longo e fino aumentou no intervalo de tempo avaliado, provavelmente em razão da demanda de mercado. Conforme os dados moleculares, houve aumento na variabilidade genética e, por meio da análise fatorial de correspondência, observou-se que a maior parte dos acessos foi agrupada de acordo com o ano de coleta. A incorporação de cultivares modernas de arroz às áreas de cultivo das variedades locais e a seleção realizada pelos pequenos agricultores são, provavelmente, os fatores responsáveis pelo aumento observado na variabilidade genética, ao longo do período avaliado. $\mathrm{O}$ intercâmbio de genótipos entre fazendeiros, a prática da seleção e a adaptação ambiental ao local de cultivo são capazes de gerar novas combinações alélicas adaptadas que, por sua vez, podem ser usadas pelos programas de melhoramento, para reiniciar o processo.

Termos para indexação: Oryza sativa, genotipagem, microssatélites, melhoramento participativo, melhoramento de arroz.

\section{Introduction}

Rice (Oryza sativa) is the main crop used for staple diet in Brazil, where it is cultivated from subtropical to tropical climates, in irrigated or upland cultivation systems. Until the decade of 1930, when rice breeding programs initiated in Brazil, the unique source of rice varieties was the germplasm introductions from abroad (Pereira, 2002). The introduced varieties and old rice cultivars from breeding programs constitute today the Brazilian rice landrace's genetic basis. To preserve the genetic variability in rice landraces, Embrapa established, in 1976, a program of germplasm collection expeditions (and posterior storage at Embrapa Genebank) throughout several states in Brazil (Fonseca et al., 2002). After 20 expeditions, more than 5,000 landrace accessions were collected, guaranteeing the rice genetic variability preservation for the future, as a source of genes of potential agricultural interest.

According to Lanteri \& Barcaccia (2006), landraces have the higher genetic variability among the 
different groups of germplasm, as well as the better environmental adaptation, and are an irreplaceable source of highly co-adapted genotypes. As a natural source of genes for disease and insect tolerance, these materials have also a high potential to increase the genetic basis of elite rice lines and cultivars. Narrow genetic basis is traditionally pointed out as the main reason for the stagnation of genetic gains of rice breeding programs, and for the increase of pest and disease susceptibilities in modern rice cultivars in Brazil and worldwide (Tanksley \& McCouch, 1997; Castro et al., 1999).

In the Brazilian state of Goiás, rice landraces, historically grown by small farmers, are representative of an agricultural model that has not changed over time, based on low use of fertilizers and pesticides. The genetic variability found in rice landraces is well documented, and the main reasons of its occurrence are the genetic factors involved in changes of allele frequencies acting on each landrace, such as cross pollination and migration, seed mixture, founder effect, genetic drift, or adaptability selection (Tin et al., 2001; Barry et al., 2007). The amount of genetic variability of a species is essential for its survival and adaptation in different environments. The loss of this variability is known as genetic erosion and, although it is well described, there is little information about its rate, identification of critical areas and evaluation of diversity based on molecular markers (Gao, 2003). Studies of genetic diversity using molecular markers are necessary to understand the genetic structure of a population and to orientate effective strategies of germplasm conservation. The usefulness of SSR markers for rice germplasm characterization is described in studies on landraces (Thomson et al., 2007), cultivars (Garris et al., 2005; Lu et al., 2005) and different species of Oryza (Brondani et al., 2003).

In Brazil, rice is probably the crop that had the higher reduction in the number of landraces under cultivation, motivated by rural exodus or due to their replacement by commercial cultivars (Fonseca et al., 2006). The objective of this work was to evaluate the impact of these changes on the genetic variability of Brazilian rice landraces, collected in almost two decades interval, in small farms of Goiás state.

\section{Materials and Methods}

A sample of 417 upland landraces were obtained from small farmers' fields from 64 cities in Goiás state, Brazil, after three germplasm expeditions done in 1986, 1987 and 2003. In 1986, 137 accessions were sampled in the following counties: Americano do Brasil, Anicuns, Carmo do Rio Verde, Ceres, Goiânia, Goiás, Itaberaí, Itapaci, Itapuranga, Jaraguá, Jussara, Mossâmedes, Moiporá, Nova Glória, Petrolina de Goiás, Rialma, Rianópolis, Rubiataba, Sanclerlândia, Santa Bárbara de Goiás, São Francisco de Goiás, São Luís de Montes Belos, Trindade. In 1987, 112 accessions were sampled in the following counties: Alvorada do Norte, Cachoeira Alta, Caçú, Edéia, Goiânia, Goiatuba, Guapo, Hidrolândia, Indiara, Itarumã, Jandaia, Jataí, Paraúna, Piracanjuba, Pontalina, Rio Verde, Santa Helena de Goiás, Santo Antônio de Goiás, Varjão. In 2003, 168 accessions were sampled in the following counties: Alto Paraíso de Goiás, Campestre de Goiás, Carmo do Rio Verde, Cavalcante, Colinas do Sul, Diorama, Faina, Heitoraí, Iporá, Itaberaí, Itapaci, Itapirapuã, Itapuranga, Jaraguá, Goiás, Matrinchã, Minaçu, Montes Claros de Goiás, Mossâmedes, Nazário, Niquelândia, Nova Glória, Novo Brasil, Palmeiras de Goiás, Pilar de Goiás, Rialma, Sanclerlândia, Santa Isabel, Santa Terezinha de Goiás, São Francisco de Goiás, São João da Aliança, São Luís de Montes Belos, São Patrício, Teresina de Goiás, Trindade.

The rice landraces were classified according to their common name, as given by farmers at the moment of the germplasm collection.

Each landrace was analyzed as a bulk constituted by four plants. The total genomic DNA was extracted according to Brondani et al. (2002). Twelve SSR markers were selected by their higher polymorphism and their representativeness of the twelve rice chromosomes. The polymerase chain reaction (PCR) was performed in a final volume of $13 \mu \mathrm{L}$ containing $0.3 \mu \mathrm{mol} \mathrm{L}^{-1}$ of each primer (forward and reverse), $1 \mathrm{X}$ reaction buffer $\left(50 \mathrm{mmol} \mathrm{L}^{-1} \mathrm{KCl}, 10 \mathrm{mmol} \mathrm{L}^{-1}\right.$ Tris- $\mathrm{HCl}$ $\mathrm{pH} \quad 8.4,0.1 \%$ Triton $\mathrm{X}-100$ and $1.5 \mathrm{mmol} \mathrm{L}^{-1}$ $\mathrm{MgCl}_{2}$ ), $0.22 \mathrm{mmol} \mathrm{L}^{-1} \mathrm{dNTP}$, DMSO 5\%, $7.5 \mathrm{ng}$ of template DNA and one unit of the Taq DNA polymerase enzyme. PCR was conducted in a 
PT-100 thermocycler (MJ Research, Waltham, Massachusetts, USA), and the amplification conditions were one step of $2 \mathrm{~min}$ at $96^{\circ} \mathrm{C}$, followed by 30 cycles of $1 \mathrm{~min}$ at $94^{\circ} \mathrm{C}, 1 \mathrm{~min}$ at $56^{\circ} \mathrm{C}$, and $1 \mathrm{~min}$ at $72^{\circ} \mathrm{C}$, with a final extension of $7 \mathrm{~min}$ at $72{ }^{\circ} \mathrm{C}$. The PCR products were loaded in a $6 \%$ denaturing polyacrylamide gel (urea $7 \mathrm{~mol} \mathrm{~L}^{-1}$ ), and were silver-stained according to Bassam et al. (1991). The standard fragment size used was a 10 bp ladder (Invitrogen, Carlsbad, California, USA).

The number of private (exclusive) alleles was estimated by the program Genetic Data Analysis (GDA) (Lewis \& Zaykin, 1997). The number of alleles per locus and the polymorphism information content (PIC) values were determined by PowerMarker version 3.23 (Liu \& Muse, 2005). The genetic distance among the accessions was calculated using the Rogers coefficient modified by Wright (1978), hereafter named Rogers-W, available at NTSYS (Rohlf, 1989). The program Identity (Sefc et al., 1997) was used to obtain the SSR combined probability of identity. The factorial correspondence analysis (FCA) was obtained by the program Genetix version 4.03 (Belkhir et al., 2001). The Structure program (Pritchard et al., 2000) was used to infer the population structure using a burn-in of 100,000 and a run length of 500,000 , and using prior population information to assist clustering, which allowed for admixture and correlated allele frequencies. The AMOVA was obtained by the program Arlequin version 3.0 (Excoffier et al., 2005).

\section{Results and Discussion}

Most of the accessions (250) were clustered in 16 groups, based on landrace common names given by the farmers (Table 1). The remaining 167 accessions were not grouped, since they were named as unknown by farmers, or collected in just one farm. In the 1986 expedition, the group with the higher number of accessions was "Quatro Meses" (15 accessions, or $10.9 \%$ of the collected accessions); in 1987, it was the group "Amarelo" (13 accessions, or $11.6 \%$ ), and in 2003, it was the group "Agulhinha" (21 accessions, or $12.5 \%)$. An increase in the number of landraces with common names referring to the grain type agulhinha (long and thin grain) was observed from 1986/1987 to 2003 (Tables 1 and 2). There are two possible explanations for this result. The first is related to the change of consumption preference by the Brazilian population, who preferred long and thick rice grains or round ("cateto") grain type in the past, both sticky after cooking. Since the 1970 decade, the preference is for long, thin and loosen rice grains after cooking (Castro et al., 1999). To address the market demand, farmers initiated the cultivation

Table 1. Number of accessions on each group based on common names of Brazilian rice landraces collected in Goiás state, in 1986, 1987 and 2003, and average genetic distance obtained by Rogers-W coefficient.

\begin{tabular}{|c|c|c|c|c|c|}
\hline Group & 1986 & 1987 & 2003 & Difference $[(2003)$ - $(1986 / 1987)]$ & Average distance (Rogers-W) \\
\hline Três Meses & 8 & 10 & 5 & -13 & 0.64 \\
\hline Três Meses Amarelo & 2 & 3 & - & -5 & 0.46 \\
\hline Três Meses Branco & 1 & 3 & 3 & -1 & 0.67 \\
\hline Quatro Meses & 15 & 6 & 6 & -15 & 0.65 \\
\hline Agulha Branco & - & 1 & 3 & 2 & 0.89 \\
\hline Agulhão & - & - & 7 & 7 & 0.75 \\
\hline Agulhinha & 6 & 4 & 21 & 11 & 0.75 \\
\hline Agulhinha Amarelo & - & 1 & 6 & 5 & 0.73 \\
\hline Amarelo & 7 & 13 & 17 & -3 & 0.66 \\
\hline Bico-Ganga & 8 & 1 & 14 & 5 & 0.67 \\
\hline Bico-Preto & 7 & 4 & 3 & -8 & 0.63 \\
\hline Branco & 12 & 7 & 1 & -18 & 0.58 \\
\hline Guaíra & 5 & 8 & 1 & -12 & 0.61 \\
\hline IAC 12 & 5 & - & 2 & -3 & 0.57 \\
\hline Pratão & 1 & 3 & 2 & -2 & 0.71 \\
\hline Preto & 3 & 6 & 9 & 0 & 0.71 \\
\hline Subtotal & 80 & 70 & 100 & - & - \\
\hline Unknown & 18 & 7 & 14 & - & 0.67 \\
\hline Not grouped & 39 & 35 & 54 & - & 0.72 \\
\hline Total & 137 & 112 & 168 & - & - \\
\hline
\end{tabular}


of rice varieties with commercial acceptance. The second reason, and a consequence of the first, is related to the inset of modern rice cultivar seeds in small farms. After years of cultivation in a system which tends to favor the recombination and mixture of genotypes, those rice cultivars accumulated genetic variability to be, eventually, considered as landraces. Except for the "Bico Ganga" landrace, all the other groups with traditional grain types (thick grain, sticky after cooking) had reduced their number in collected accessions. Tin et al. (2001) observed that grain uniformity is one of the main criteria used in landrace selection by small farmers in Vietnam, in addition to environmental adaptation and to market-oriented traits, such as grain quality. Probably the same occurred in Goiás state, where the market requirements directed the farmers' selection to agulhinha grain type.

Analyses of 417 accessions with the 12 SSR markers (combined probability of identity of $6,04 \times 10^{-9}$ ) identified 200 alleles: average of 16 alleles per locus, with a maximum of 31 alleles detected by marker OG106, and a minimum of seven alleles detected by marker RM231. The average PIC was 0.55 , ranging from 0.9 (marker OG106) to 0.12 (marker RM252) (Table 3). Forty-one private alleles were found, seven of them with the marker
RM252. The accessions with the higher number of private alleles were: "Mistura" and "Quatro Meses", with three alleles, and "Quatro Meses", "Agulhinha", "Doidão" and "Rio Paranaíba", with two alleles. The presence of private alleles indicates a unique genetic variability in certain loci. This information is useful to identify accessions with exclusive genetic variability, whose selection can increase the allele richness of genebanks.

The genetic variability found in this work, represented by the average allele numbers, PIC, and private alleles, was superior to those found in previous SSR genotyping works with rice landraces (Brondani et al., 2006; Thomson et al., 2007). The genetic variability found on each landrace, determined by Rogers-W distance coefficient, varied from 0.46 ("Três Meses Amarelo") to 0.89 ("Agulha Branco") (Table 1). This was probably a consequence of several events operating independently or simultaneously, e.g., seed mixture, cross pollination, selection and genetic drift caused by reduced sampling of seeds to be used in the next rice crop season. In this case, an original landrace, after years of successive cultivation, would generate populations with a genetic constitution different from the original genotype (Brondani et al., 2006;

Table 2. Average grain (caryopsis) measures and standard deviations (SD) of 417 Brazilian rice landraces.

\begin{tabular}{|c|c|c|c|c|c|c|c|c|c|c|}
\hline \multirow[t]{2}{*}{ Year } & \multicolumn{2}{|c|}{ Length (mm) } & \multicolumn{2}{|c|}{ Width (mm) } & \multicolumn{2}{|c|}{ Length/width ratio } & \multicolumn{2}{|c|}{ Grain type $^{(1)}$} & \multicolumn{2}{|c|}{ Weight of 1,000 grains $(\mathrm{g})$} \\
\hline & Average & SD & Average & SD & Average & $\mathrm{SD}$ & Average & $\mathrm{SD}$ & Average & $\mathrm{SD}$ \\
\hline 1986 & $7.0(7.9-5.0)$ & 0.33 & $2.6(2.9-1.9)$ & 0.15 & $2.7(3.5-1.8)$ & 0.22 & $1.9(3-1)$ & 0.35 & $30(45-17)$ & 3.70 \\
\hline 1987 & $7.1(9.3-5.1)$ & 0.58 & $2.6(3.0-2.0)$ & 0.14 & $2.8(3.7-1.8)$ & 0.30 & $1.9(3-1)$ & 0.47 & $30(40-16)$ & 3.14 \\
\hline 2003 & $7.1(8.3-5.8)$ & 0.42 & $2.4(2.9-1.9)$ & 0.23 & $3.0(3.8-2.0)$ & 0.35 & $1.4(3-1)$ & 0.52 & $27(35-15)$ & 3.94 \\
\hline
\end{tabular}

(1) 1 , long-thin; 2, long; 4, short. Value between parentheses refers to data range.

Table 3. Chromosomal location, allele number, polymorphism information content (PIC), and number of private alleles obtained through SSR marker analyses of 417 Brazilian rice landraces $^{(1)}$.

\begin{tabular}{lccc}
\hline SSR marker & Chromosomal location & Allele number & PIC \\
\hline RM9 & 1 & $18(14,10)$ & $0.63(0.50,0.68)$ \\
OG17 & 2 & $10(6,7)$ & $0.24(0.07,0.40)$ \\
RM231 & 3 & $7(6,4)$ & $0.37(0.26,0.47)$ \\
RM252 & 4 & $15(8,9)$ & $0.12(0.07,0.14)$ \\
OG61 & 5 & $25(21,16)$ & $0.77(0.73,0.79)$ \\
RM204 & 6 & $16(10,13)$ & $0.28(0.21,0.35)$ \\
RM248 & 7 & $12(8,10)$ & $0.48(0.21,0.67)$ \\
RM223 & 8 & $19(14,16)$ & $0.82(0.69,0.84)$ \\
OG106 & 9 & $31(24,26)$ & $0.90(0.86,0.88)$ \\
RM304 & 10 & $16(13,13)$ & $0.57(0.31,0.72)$ \\
OG7 & 11 & $11(10,10)$ & $0.66(0.48,0.69)$ \\
RM247 & 12 & $20(15,19)$ & $0.81(0.64,0.87)$ \\
\hline Total & - & $200(149,153)$ & - \\
Average & - & $16.7(12.4,12.8)$ & $3(3,11)$ \\
\hline
\end{tabular}

${ }^{(1)}$ Values between parentheses are relative to the accessions collected in 1986/1987 and 2003, respectively. 
Barry et al., 2007). The average Rogers-W distance coefficient was higher among accessions collected in 2003 (Rogers-W $=0.72$ ), in comparison to the accessions collected in 1986 and 1987 (Rogers-W $=0.6$ ). This increase was probably due to the introduction of new genetic variability from modern rice cultivars into the genetic background of landraces cultivated in Goiás. For example, the higher average Rogers-W obtained within groups of accessions was observed for "Agulha Branco" (0.89) and, on average, "Agulha" groups had the Rogers-W coefficient of 0.76 , whereas the groups with traditional grain type had an average Rogers-W coefficient of 0.6 .

Factorial correspondence analyis grouped most of the accessions according to their respective year of collection (Figure 1). However, these groups were not genetically structured, according to the analysis of molecular variance (AMOVA) and a model-based clustering method for multilocus genotypes. The AMOVA showed that the greater percentage of total variation was related to accessions within cities (Table 4). By the model-based clustering method, the population structure had a maximized probability of the data (highest likelihood) when the number of populations (K) was set at one. These two results indicate that the incorporation of genes and alleles from modern rice cultivars into the gene pool of rice landraces increased the overall genetic variability of the last ones, as a result of the introduction, not substitution, of newly improved rice to the landrace cultivation areas. This process can alter the original population structure and can establish the condition to the random genetic drift, which will be the starting point to the natural or artificial selection of the best allele and gene combinations (Tin et al., 2001; Gao, 2003).

On farm conservation of landraces is useful to preserve the evolutionary process, which generates new genotypes under natural selection (Gao, 2003) and, for this reason, the small farmers must be stimulated to keep cultivating this important germplasm in Brazil. The genetic improvement of rice landraces can be optimized if oriented by researchers, since the genetic variability can be increased in addition to incorporation of economically important traits. This could be accomplished by the promotion of exchange of seeds between farmers in a community (Sirabnachongkran, 2004), under the supervision of breeders, or by the development of participatory breeding (Morris \& Bellon, 2004), in which the farmers' participation is encouraged during the development of rice lines and cultivars. Steele et al. (2009) observed that three cultivars developed by participatory breeding replaced some rice landraces in Nepal, and this increased the genetic variability available to farmers. As a counterpart, the collaborative effort between farmers and breeders can also generate rice cultivars with increased environmental adaptation.

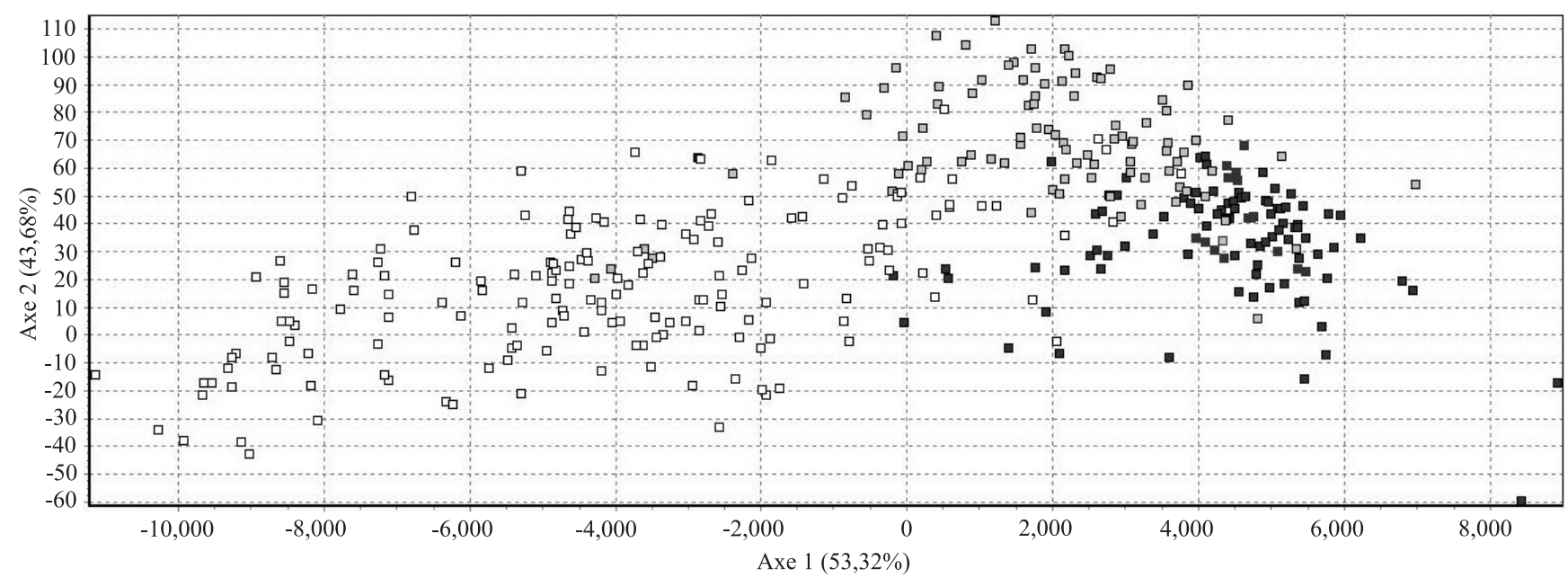

Figure 1. Factorial correspondence analysis of rice landraces collected in 1986 (black), 1987 (gray) and 2003 (white), based on SSR markers data. 
Table 4. Summary of the analyses of molecular variance.

\begin{tabular}{lccc}
\hline $\begin{array}{l}\text { Source } \\
\text { of variation }\end{array}$ & d.f. & $\begin{array}{c}\text { Sum of } \\
\text { square }\end{array}$ & $\begin{array}{c}\text { Percentage of } \\
\text { total variation }\end{array}$ \\
\hline Among years & 2 & $0.43^{* * *}$ & 12.55 \\
Among cities within years & 75 & $0.57 * * *$ & 16.70 \\
Among accessions within cities & 794 & $2.41^{* * *}$ & 70.75 \\
\hline Total & 871 & 3.41 & - \\
\hline
\end{tabular}

*** Significant at $0,01 \%$.

\section{Conclusions}

1. The genetic variability of rice landraces increased in Goiás state, from 1980 to 2000 decades.

2. The incorporation of modern rice cultivars in landrace cultivation areas and the selection carried out by small farmers are the most probable factors responsible for increasing landraces' genetic variability, during the evaluated period.

3. Genotype exchange between farmers, selection practices and local environmental adaptation are able to generate novel adapted allele combinations, which can be used by breeding programs to reinitiate the process.

\section{References}

BARRY, M.B.; PHAM, J.L.; COURTOIS, B.; BILLOT, C.; AHMADI, N. Rice genetic diversity at farm and village levels and genetic structure of local varieties reveal need for in situ conservation. Genetic Resources and Crop Evolution, v.54, p.1675-1690, 2007.

BASSAM, B.J.; CAETANO-ANOLLÉS, G.; GRESSHOFF, P.M. Fast and sensitive silver staining of DNA in polyacrilamide gels. Analytical Biochemistry, v.196, p.80-83, 1991.

BELKHIR, K.; BORSA, P.; CHIKHI, L.; RAUFASTE, N.; BONHOMME, F. GENETIX, logiciel sous Windows ${ }^{\mathrm{TM}}$ pour la génétique des populations. Montpellier: Université de Montpellier II, 2001. 45p.

BRONDANI, C.; BORBA, T.C.O.; RANGEL, P.H.N.; BRONDANI, R.P.V. Determination of genetic variability of traditional varieties of Brazilian rice using microsatellite markers. Genetics and Molecular Biology, v.29, p.676-684, 2006.

BRONDANI, C.; RANGEL, P.H.N.; BORBA, T.C.O.; BRONDANI, R.P.V. Transferability of microsatellite and sequence tagged site markers in Oryza species. Hereditas, v.138, p.187-192, 2003.

BRONDANI, C.; RANGEL, P.H.N.; BRONDANI, R.P.V.; FERREIRA, M.E. QTL mapping and introgression of yield-related traits from Oryza glumaepatula to cultivated rice (Oryza sativa) using microsatellite markers. Theoretical and Applied Genetics, v.104, p.1192-1203, 2002.
CASTRO, E. da M. de; VIEIRA, N.R. de A.; RABELO, R.R.; SILVA, S.A. da. Qualidade de grãos em arroz. Santo Antônio de Goiás: Embrapa Arroz e Feijão, 1999. 30p.

EXCOFFIER, L.; LAVAL, G.; SCHNEIDER, S. Arlequin (version 3.0): an integrated software package for population genetics data analysis. Evolutionary Bioinformatics Online, v.1, p.47-50, 2005.

FONSECA, J.R.; BRONDANI, C.; BRONDANI, R.P.V.; RANGEL, P.H.N. Recursos genéticos do arroz. In: SANTOS A.B.; STONE, L.F.; VIEIRA, N.R. de A. (Ed.). A cultura do arroz no Brasil. Santo Antônio de Goiás: Embrapa Arroz e Feijão, 2006. p.257-288.

FONSECA, J.R.; VIEIRA, E.H.N.; SILVA, H.T. da; CUTRIM, V. dos A.; CASTRO, E. da M. Coleta de germoplasma de arroz Oryza sativa L. no Brasil. In: CONGRESSO DA CADEIA PRODUTIVA DE ARROZ, 1.; REUNIÃO NACIONAL DE PESQUISA DE ARROZ, 7., 2002, Florianópolis. Anais. Santo Antônio de Goiás: Embrapa Arroz e Feijão, 2002. p.249-250. (Embrapa Arroz e Feijão. Documentos, 134).

GAO, L. The conservation of Chinese rice biodiversity: genetic erosion, ethnobotany and prospects. Genetic Resources and Crop Evolution, v.50, p.17-32, 2003.

GARRIS, A.J.; THOMAS, H.T.; COBURN, J.; KRESOVICH, S.; MCCOUCH, S. Genetic structure and diversity in Oryza sativa L. Genetics, v.169, p.1631-1638, 2005.

LANTERI, S.; BARCACCIA, G. Molecular marker based analysis for crop germplasm preservation. In: RUANE, J.; SONNINO, A. (Ed.). The role of biotechnology in exploring and protecting agricultural genetic resources. Rome: FAO, 2006. p.55-66.

LEWIS, P.O.; ZAYKIN, D. Genetic data analysis: software for the analysis of discrete genetic data. Version 1.0. Sunderland: Sinauer Associates, 1997.

LIU, K.J.; MUSE S.V. PowerMarker: an integrated analysis environment for genetic marker analysis. Bioinformatics, v.21, p.2128-2129, 2005.

LU, H.; REDUS, M.A.; COBURN, J.R.; RUTGER, J.N.; MCCOUCH, S.R.; TAI, T.H. Population structure and breeding patterns of 145 U.S. rice cultivars based on SSR marker analysis. Crop Science, v.45, p.66-76, 2005.

MORRIS, M.L.; BELLON, M.R. Participatory plant breeding research: opportunities and challenges for the international crop improvement system. Euphytica, v.136, p.21-35, 2004.

PEREIRA, J.A. Cultura do arroz no Brasil: subsídios para a sua história. Teresina: Embrapa Meio Norte, 2002. 226p.

PRITCHARD, J.K.; STEPHENS, M.; DONNELLY, P. Inference of population structure using multilocus genotype data. Genetics, v.155, p.945-959, 2000.

ROHLF, F.J. NTSYS-pc: numerical taxonomy and multivariate analysis system. New York: Exeter, 1989. 126p.

SEFC, K.M.; STEINKELLNER, H.; WAGNER, H.W.; GLÖSSL, J.; REGNER, F. Application of microsatellite markers to parentage studies in grapevine. Vitis, v.36, p.179-183, 1997.

SIRABNACHONGKRAN，A.; YIMYAM，N.; BOONMA, W.; RERKASEM, K. Varietal turnover and seed exchange: implications for conservation of rice genetic diversity on-farm. International Rice Research Notes, v.29, p.18-20, 2004. 
STEELE, K.A.; GYAWALI, S.; JOSHI, K.D.; SHRESTHA, P.; STHAPIT, B.R.; WITCOMBE, J.R. Has the introduction of modern rice varieties changed rice genetic diversity in a high-altitude region of Nepal? Field Crops Research, v.113, p.24-30, 2009.

TANKSLEY, S.D.; MCCOUCH, S.R. Seed banks and molecular maps: unlocking genetic potential from the wild. Science, v.277, p.1063-1066, 1997.

THOMSON M.J.; SEPTININGSIH, E.M.; SUWARDJO, F.; SANTOSO, T.J.; SILITONGA, T.S.; MCCOUCH, S.R. Genetic diversity analysis of traditional and improved Indonesian rice (Oryza sativa L.) germplasm using microsatellite markers. Theoretical and Applied Genetics, v.114, p.559-568, 2007.

TIN, H.Q.; BERG, T.; BJØRNSTAD, Å. Diversity and adaptation in rice varieties under static (ex situ) and dynamic (in situ) management. Euphytica, v.122, p.491-502, 2001.

WRIGHT, S. Evolution and the genetics of populations. Chicago: University of Chicago Press, 1978. 360p.

Received on February 16, 2009 and accepted on June 29, 2009 